International Journal of Linguistics, Literature and Translation

ISSN: 2617-0299 (Online); ISSN: 2708-0099 (Print)

DOI: $10.32996 / \mathrm{ijllt}$

Journal Homepage: www.al-kindipublisher.com/index.php/ijllt

\title{
Transcending Self-Consciousness: Imagination, Unity and Self-Dissolution in the English Romantic and Sufis Epistemology
}

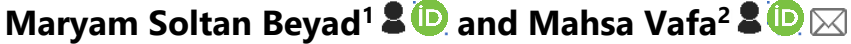 \\ ${ }^{1}$ Associate Professor of English Language and Literature, Faculty of Foreign Languages and Literatures, University of Tehran, \\ Tehran, Iran \\ ${ }^{2} \mathrm{PhD}$ Candidate of English Language and Literature, Faculty of Foreign Languages and Literatures, University of Tehran, Tehran, \\ Iran
}

$\triangle$ Corresponding Author: Mahsa Vafa, E-mail: vafa.mahsa@ut.ac.ir, vafa.mahsa@gmail.com

\section{ARTICLE INFORMATION}

Received: July 09, 2021

Accepted: August 10, 2021

Volume: 4

Issue: 8

DOI: $10.32996 /$ ijllt.2021.4.8.2

\section{KEYWORDS}

Romanticism, Sufism, Imagination, Unification, Self-dissolution, Fana

\section{ABSTRACT}

English Romantic literature of the late eighteenth and early nineteenth centuries often recounts an individual life journey which depicts physical and spiritual pilgrimage and traverses both the inner and outer world to liberate the self and reach a revelatory moment of unification where the division between human mind and the external world is reconciled. For the Romantic poets this reconciliatory state cannot be achieved through rational investigation but via the power of imagination. In this regard, there is striking resemblance between the mystical and philosophical thought of Sufism and the idealistic thought of the English Romantic poets as they both strive for a sense of unification with the Divine or the Ultimate reality, and they both rely on imagination and intuitive perception to apprehend reality. Applying an analyticalcomparative approach with specific reference to Northrop Frye's anagogic theory (1957) which emphasizes literary commonalities regardless of direct influence or cultural or theological distinctions, this study endeavors to depict that certain Romantic poets' longing for the reconciliation of subject and object dualism via imagination and its sublime product, poetic language, echoes the mystic's pursuit of transcendental states of consciousness and unification with the divinely infinite. Through analysis of the concept of self-dissolution (fana) in Islamic mysticism and Sufi literature, particularly the poems of Jalal ad-Din Mohammad Balkhi (1207-1273) known in the West as Rumi, the outcome of this study reveals that the Romantics' yearning for a state of reconciliation, which is prevalent in the major works of the Romantic poets such as William Blake (1757-1827), William Wordsworth (1770-1850), Samuel Taylor Coleridge (1772-1834), Percy Bysshe Shelley (1792-1822), and John Keats (1795-1821), corresponds to the mystic's pursuit of unity or the Sufi's concept of self-annihilation or fana.

\section{Introduction}

The Romantic period was an epoch of significant political and philosophical transformations which witnessed an increasing conflict between traditional Christianity and the skeptical rationalism of the Enlightenment. In the years following the American and French revolutions, numerous artists and writers, disillusioned by the shattered promises and failed utopias of the Enlightenment, translated key religious themes and ideas into more secular terms. The collapse of the promise of the French Revolution was a traumatic blow to the Romantic poets who live through it, yet for them the French Revolution remained a vision of a lost paradise, and the language of Utopian idealism and apocalyptic vision prevailed the Romantic writings even when the political ambition of attainment of such goals in the external world had been perished. As Abrams argues as a result of

\begin{tabular}{ll|lll}
$\mathbf{K}$ & $\mathbf{C}$ & AL-KINDI CENTER \\
$\mathbf{R}$ & $\mathbf{D}$ & FOR RESEARCH AN
\end{tabular} $\mathbf{R}$ D DEVELOPMENT Your gateway to world-class research

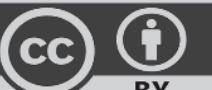

Published by Al-Kindi Center for Research and Development, London, United Kingdom. Copyright (c) the author(s). This open access article is distributed under a Creative Commons Attribution (CC-BY) 4.0 license 
disillusionment with fulfilling the revolutionary promise, the Romantic writers internalize the political concepts and the millennial hope of the Revolution, "by translating them into mental, moral and cognitive terms" (1973, p. 350).

After the failure of the political and social dreams of the French Revolution, the Romantic messianic program turned into increasingly religious terms. Ryan regards the literature of the Romantic period as a conscious attempt by a group of writers to influence the religious transformation that was taking place in their society and calls what the Romantics endeavored to do a "reformation" because "after periods of youthful iconoclasm, they all finally became more interested in purifying or redefining England's national religion than in attempting to eradicate it" (1997, p. 7). As Ryan argues, "instead of lamenting Romanticism as a political retreat, then, one may more usefully see it as a creative and effective engagement in the contemporary religious crisis, an engagement that was perceived as having far-reaching consequences in the political order" (Ibid. p. 5).

Abrams, in his monumental work on Romanticism, Natural Supernaturalism (1973), seeks to demonstrate the survival and transformation of religious patterns of thought in the Romantic period which, he believes, are rooted in political and apocalyptic expectations of the Romantic writers. He sees Wordsworth's "Prospectus" to The Recluse as the concept of the spiritual resurrection of mankind by the holy marriage of nature to the mind of man and he regards this union with nature as a consolation and substitute for the shattered revolutionary dreams. As Wordsworth says in The Prelude of 1805, with a loss of faith in the revolutionary promises, in a time "...of hopes overthrown... Of dereliction and dismay" (II, 449-457), in which "moral questions" are "Yielded up...in despair" (1805, X, 900), consciousness turns inwards and "faith in an apocalypse by revelation had been replaced by faith in an apocalypse by revolution, and this now gave way to faith in an apocalypse by imagination or cognition" (Abrams, 1973, p. 334).

In addition to disenchantment with fulfilling the revolutionary promise, Romanticism as a literary period began as a reaction against empiricism and the increasing rationalism during the Enlightenment. The Romantics believed that empirical philosophy, through insisting that all knowledge was ultimately derived from sensation, would inevitably undermine the belief in the reality of anything spiritual. The philosophers of the Enlightenment had attacked all institutions and creeds which could not withstand the test of reason. The Romantics, on the contrary, bewailed over the damage inflicted upon the spiritual aspect of human life by mere reliance on reason. They believed in inadequacy of the reason of the Enlightenment philosophy to explain some of the most fundamental human experiences, such as "poetic imagination", the "sublime", and "revelation" (Perkins, 2002, p. 191), and dismissively named that reason "the mere analytical understanding" which "usurped the name of reason," and became "the pander and prostitute of sensuality" (Coleridge, 1971, p. 75).

According to the Romantics, the mechanical philosophy of Enlightenment by enslaving the mind to the "sensuous eye" impedes the operation of imagination, thus they aim to establish the sovereignty of imaginative vision in their poetry. Romantic epistemology is on the basis of the ultimate superiority of imagination over the logical and speculative reason of the Enlightenment. While the rationalistic epistemology of Enlightenment is grounded on dualism, Romantic philosophy of aesthetics aspires towards an overcoming of dualism and reaching a state of reconciliation in which a unification of dialectically opposed entities is achieved. To combat the oppressive dominance of the Enlightenment, Romantic writers and poets utilize a specific type of quasi-mystical language which entails privileging intuition and imagination over rational awareness. Such language challenges the foundation of Western though _ the subject/object dichotomy, bridges the Cartesian schism, the separation of mind and matter and causes "a radical orientation towards nature that overcomes what Heidegger called 'Gestell', the technological attitude, in which nature is subjugated for the use of humankind" (Moores, 2006, p. 17).

The implementation of mystical discourse by the Romantic writers can be viewed as a form of ideological resistance to what they call the mechanical philosophy of Enlightenment. In addition to Christian mysticism, in Romantic poetry, one can discern experiences and state of consciousness like those state of illuminations and ecstasies prevalent in earlier bards and prophets and other types of mysticism particularly Islamic mysticism or what in the Western world is known as Sufism which is the main focus of this study.

\subsection{Literature Review}

There are striking resemblances between the mystical and philosophical thought of Sufism and the mystical and idealistic thought to be found in the English Romantic poets. Despite the fascinating similarities between Romanticism and Sufism, there have been surprisingly few comparative studies done on the two of them. For example, Leonard Lewisohn, in an essay entitled "Correspondence Between English Romantic and Persian Sufi Poets" (2009), investigates common themes and motifs that British Romantic poets and Persian Sufi poets such as Rumi, Hafez, Attar, Shaykh Mahmud Shabistari, and Shaykh Baha'i share in common. Lewisohn refers to the parallels and convergence in both content and intent in the verse of the Sufi mystics and poets and the English Romantic poets due to a huge intellectual common ground between both poetic traditions, and he regards Plato's thought and Neoplatonism as the most important aspect of the mutual philosophical heritage shared by these Christian Romantic and Muslim Sufi poets and mystics (p. 189). Parvin Loloi also in "Byron in Persian Costume" (1988) points to a significant influence of Hafez on the English Romantic poets through the agency of eighteenth century orientalists, particularly 
Sir William Jones (1746-1794). There are also authors, such as John Draper in "Shelley and Arabic-Persian Lyric Style" (1960) and Mehdi Aminrazavi in Sufism and American Literary Masters (2014) who have already elaborated on some of the correspondences that do exist between Romanticism and Sufism.

\subsection{Aims and Findings}

Despite the palpable ideological and cultural distinction, there is sufficient evidence that both the Romantics and the Sufis support the mystical doctrine of unity of being and that they both rely on intuitive knowledge to comprehend reality and get a glimpse into the transcendental realm. A belief in unity of all beings and a yearning to transcend self-consciousness to come to a state of harmony or reconciliation with nature through intuition and imagination seem to underline both the Romantic and Sufi philosophical doctrines. Furthermore, the Romantic notion of the "marriage of mind and nature" or "the coalescence of subject and object" resonates the mystical notion of merging the self with the Godhead.

This study does not attempt to trace the channels through which Sufi doctrines have been transmitted to the Romantic writers. However, there is no doubt that such specific channels could easily be found not only through the agency of German writers who were steeped in Sufi poetry and philosophical doctrines and had an immense influence on Coleridge's philosophical beliefs and aesthetic theory but also via an increasing number of orientalists who throughout the eighteenth and nineteenth centuries produced a huge body of literature, either translating and adapting from original texts or producing travelogues from their own observations and inspirations of the Orient. The purpose of this study is neither to label the Romantic poets as actual mystics as a result of the abundance of mystical elements in their works. Applying an analytical-comparative approach with specific reference to Northrop Frye's anagogic theory elaborated in his Anatomy of Criticism (1957), this study attempts to substantiate that certain Romantic poets' yearning to attain a unity of subject and object through imagination and its sublime product, poetic language, corresponds to the mystic's longing for transcendental states of consciousness and unification with the divinely infinite.

Anagogic criticism is an approach to comparative literature which, according to Frye, transcends cultural confinements or limitation of specific civilization in dealing with literary interpretation and is concerned with the "universal meaning" within the exoteric literary symbols since "some symbols are images of things common to all men, and therefore have a communicable power which is potentially unlimited" (1957, p. 118). Anagogically speaking, the universe of literature is "infinite and boundless" and cannot to be "contained within any actual civilization or set of moral values" (p. 120). Therefore, in the anagogic phase, as Frye explains, "literature imitates the total dream of man, and so imitates the thought of a human mind which is at the circumference and not at the center of its reality" (p. 119). Relying on anagogic perspective, this article illustrates that the Romantics' yearning for a state of reconciliation and their pursuit of unity, which is prevalent in the major works of the Romantic writers such as William Blake (1757-1827), William Wordsworth (1770-1850), Samuel Taylor Coleridge (1772-1834), Percy Bysshe Shelley (1792-1822), and John Keats (1795-1821), echoes the mystic's longing for unity with the divine or the Sufis' concept of dissolution of selfhood in the Godhead which in Sufi terminology is known as fana. To this end, first the critical role of imagination in the process of perception in the epistemology of both Romanticism and Sufism need to be explored.

\section{In Pursuit of Unity: Imagination and Unity in the Romantic and Sufis Epistemology}

At the root of Romantic poetry lies a longing for unity underlying the multiplicity. That is, the Romantics are deeply concerned with the mind's progression from a disintegrated ego into a state of unification where the dualism between human mind and nature is reconciled. This yearning for the One and the "apprehension of the divine unifying principle behind appearance", Underhill asserts, is the ultimate object of mysticism, (1920, p. 7) which is also a pervasive theme in Romantic poetry. In mysticism, the "coalescence of subject and object" signifies the union of the individual soul or the fragmented subject with the Godhead, during a contemplative state often referred to as "the union of the many with the One" or "the merging of the drop with the Ocean" (Johnson, 1939, p. 24).

The Romantics believe that the coalescence of subject and object and the state of reconciliation cannot be realized through rational thinking but via imagination and intuitive perception. Coleridge, for instance, in Biographia Literaria (1817) regards imagination to be "the living Power and prime Agent of all human Perception" $(1975$, p. 167) and for Wordsworth imagination is "clearest insight, amplitude of mind, / And reason, in her most exalted mood (The Prelude, Book XIV, Lines 191-92). The Romantic poets' emphasis on intuition and the power of imagination to apprehend the divine unifying spirit and achieve unity with the divine parallels the Sufi's emphasis on imaginal perception rather than rational investigation to gain direct knowledge of the self and God and achieve a state of unification and illumination.

There is striking resemblance between the Romantic and Sufi notion of imagination particularly the concept of imagination in Ibn al-'Arabi's ontology. Muhyi al-Din Ibn al-'Arabi (1165-1240), popularly known to his supporters as al-Shaykh al-Akbar "the greatest Master" is one of the most influential Sufi author of the later Islamic intellectual history whose idea is most famously associated with of the doctrine of wahdat al-wujud, or the "oneness of being" and whose concept of imagination as the main 
means of perception of the divine immanence bears striking resemblance to the Romantic definition and function of imagination. One innovative notion in Ibn al-'Arabi's philosophy is the concept of imagination as the path to the perception of reality as mere reliance on intellect which only perceives divine transcendence but fails to grasp divine immanence "prevents full realization of the human potential" (Chittick, 2016, p. 12). According to Ibn al-'Arabi, the perception of God's immanence is only available through the faculty of imagination (khayal) which is the "vastest realm in existence" (Chittick, 2005, p. 117), and it is only when we perceive God through a harmonization of reason and imagination that we gain true knowledge of him. Similar to the Romantics, for Ibn al-'Arabi it is the faculty of imagination that leads to the harmonization or reconciliation of discordant qualities as it is "receptive to realities far outside the scope of intellect" (Chittick, 2016, p. 14). It is through imagination that "Awareness and unawareness, depth and surface, meaning and words, spirit and clay, inward and outward, non-manifest and manifest - all coalesce and become one" (Chittick, 2005, p. 107).

Both the Romantics and Sufis strive for a state of reconciliation or coalescence to overcome dualism which, they both believe, can be achieved through the faculty of imagination. This faculty is valued for its synthesizing capability in overcoming subjectobject dualism. For both of them, it is through the power of imagination that one can behold the Infinite Whole within the finite parts. As Engell argues a critical concern in the aesthetic philosophy of Romantic thinkers, both German and British, is the yearning towards an overcoming of dualism to which various names have been given such as "the reconcilement of antithesis", "the marriage of mind and nature", or "the synthesis of antipodes" (1981, p. 7-8). This desire is not exclusive to Romantic literary theory but is also a crucial factor in various mystical traditions especially Sufism.

For the Romantics imaginal perception is a special mode of knowing that links subject and object in an act analogous to God's creative act. Art, the creative product of the imagination, is an analogy in man for the divine's creative power. As Blake says in Annotations to Berkeley "Man is All Imagination. God is Man and exists in us and we in him" (1982, p. 664). By asserting that God is man and in man, and also that "Man is all imagination", Blake points to a key idea of the Romantic aesthetic that is the primacy of imagination and intuition. Coleridge also in chapter thirteen of Biographia Literaria highlights the divine implication of imagination when he defines the primary imagination as "a repetition in the finite mind of the eternal act of creation of the infinite I AM" (1975, p. 167). It is through the faculty of imagination that the Romantic mind can experience what the Sufis would do in terms of becoming one with the One.

In the roots of British Romantic aesthetic theory, one can witness a yearning to get to transcendental states of consciousness via the imagination and its sublime product, poetic language. They are in pursuit of a reconciliatory mode in which an alienated ego or isolated mind may be reintegrated with nature or the divine spirit in nature (Engell, 1981, p. 8). Some key figures of Romantic theory and criticism, such as Geoffrey Hartman, M. H. Abrams, and James Engell assert that the spiral movement of the ruptured selfhood or alienated ego into the imaginative state of unification is the critical concern of Romantic literature. Regarding the function of the Romantic imagination Engell claims:

The imagination held out hope and promised a reconciliation of [subject/object] dualism....with one foot in the empirical and one foot in the ideal or transcendental, [the Imagination] could bestride those two peninsulas of thought, and like a colossus, protect and unify the harbor between. The Imagination could, in its dialectic, synthesize soul and body; it could unite man's spirit and affections with the concrete reality of nature. ..It would solve the dilemma of dualism (1981, p. 7).

As Engell observes, the imagination becomes the way to "reunify man with nature, to return by the paths of selfconsciousness to a state of higher nature, a state of the sublime where senses, mind and spirit elevate themselves even as they elevate the world around them" (p. 7). Asserting that Romantic art has a function analogous to that of religion, Hartman asserts that the most crucial Romantic purpose is "to explore the transition from self-consciousness to Imagination, and to achieve that transition while exploring it" (1993, p. 50). This quasi-mystical rhetoric regards imagination as the means to overcome the problem of dualism. Similarly, Abrams observes that "Romantic philosophy is primarily a metaphysics of integration, of which the key principle is that of the 'reconciliation' or synthesis of whatever is divided, opposed and conflicting" (1973, p. 182). With respect to the role of imagination in Romantic aesthetics Engell likewise regards Romantic imagination as "the resolving and unifying force" that brings together all antitheses and contradictions and reconciles "man with nature, the subjective with the objective, the internal mind with the external world, time with eternity, matter with spirit, finite and infinite, the conscious with the unconscious and self-consciousness with the absence of self-consciousness" (1981, p. 8).

Therefore, for the Romantics the transition from self-consciousness to anti-self-consciousness, from time to timelessness and from selfhood to sympathetic imagination is associated with a sense of unity. The Romantic concern is not merely to get free from the bondage of selfhood or to liberate the mind from the oppression of the senses, but to move beyond them altogether, to get the glimpse of the transcendental state. It is via the imaginative mode of perception that the poet can unleash in Keats' words: 
A power within me of enormous ken,

To see as a God sees, and take the depth

Of things as nimbly as the outward eye

Can size and shape pervade (Fall of Hyperion, 2000, Canto I, Lines, 303-306)

Shelley captures this in A Defence of Poetry (1820) when he observes: "A poet participates in the eternal, the infinite and the one; as far as relates to his conceptions, time and place and number are not" $(2000$, p. 792$)$. A similar concept can be found in Sufi tradition, that is, for the Sufi, on the path of God's love and divine unity, temporality is the foremost hindrance. That is why Rumi asserts that "the Sufi is the son of time present" (Mathnavi, 1985, Book I, 133). As Chittick argues, in Sufi tradition God's love annihilates all "human failings and limitations. It may drive away the darkness of temporality and contingency, leaving in its place the radiance of God's own eternal being" (2000, p. 46-47). In Mathnavi, Rumi sees preoccupation with time as "what veil God from our sight" and asserts that in order to get united with God, one needs to get free from the bondage of temporality:

The way of him that has passed away (from self-consciousness) is another way,

Because sobriety is another sin.

Sobriety exists (arises) from recollection of what is past:

Past and future are to thee a curtain (separating thee) from God.

Cast fire on them both: how long, because of these twain,

Wilt thou be full of knots (joints) like a reed?

Whilst the reed is knotted, it is not a sharer of secrets:

It is not the companion of the (flute-player's) lip and voice.

(Book I. Lines, 2200-2204, trans. Nicholson, 1985)

Rumi in Mathnavi asserts that the temporal world is the world of change and in order to get liberated from this changing world and attain the eternal world of Divine Reality, one has to go beyond the confines of time:

When for a while I had taken part with that elect company

In contemplation (of God) and had been separated from myself,

At that very hour my spirit was freed from hours (of Time);

(I say 'freed') because hours make the young old."

All changes have arisen from the hours:

He that is freed from the hours is freed from change.

When for an hour you escape from the hours, relation abides not:

You become familiar with that which is without relation. (Book III, Lines, 2072-76).

Similarly, as Abrams claims, major Romantic poets testify "to a deeply significant experience in which an instant of consciousness, or else an ordinary object or event, suddenly blazes into revelation" (1973, p. 385). Romantic poetry attempts to depict in language, as Wordsworth claims, the "hidden world" which is revealed only "...when the light of sense/ Goes out in flashes..." (The Prelude, 1805, VI, 534-535), which resonates the mystical experience in which the self longs to surpass selfconsciousness and dissolve into or become one with the One. Such longing underlies the Romantic subject's quest for unity which is a quest for a state of oneness or unification where the selfhood of the subject is obliterated. As Jonathan Wordsworth claims the Romantic imagination in its essence is "the wish of a number of creative geniuses (living at a certain period, but never a group) to 'lose, and find, all self in God"' which, he asserts, is analogous to "mystical experience" (1999, p. 533). Such yearning to transcend self-consciousness and undergo self-dissolution to merge with the infinite can be defined as love, as a result of which the boundary between the self and the other is traversed and the selfhood, as Keats writes in Endymion (1818), fades into radiance of love:

There hangs by unseen film, an orbed drop

Of light, and that is love...

Melting into its radiance, we blend

Mingle, and so become a part of it (Endymion, I. Lines, 806-811)

The Romantic poets desire to overcome all dualism and reach a state of unification through reconciliation of the alienated selfhood with the transcendental Self bears striking resemblance to the Sufi concept self-annihilation or fana. Before elaborating on this resemblance, the term fana in the Sufi tradition needs to be explicated. 


\section{Sufi notion of Fana}

One essential feature of mysticism shared by all mystical traditions is an overwhelming consciousness of God and a craving for communion with Him as the Ultimate Truth and an object of love. Underhill believes that "mysticism, in its purer form, is the science of ultimates, the science of Union with the Absolute, and nothing else" (1911, p. 25). Mysticism emphasizes that the soul's path to final unification with the Absolute Life or the Godhead is only traversable once the ego or selfhood is annihilated. Mystical experience is a process through which the mystic manages to annihilate the self to achieve an illuminative state beyond the ordinary realms of man's cognitive faculties. The self thus in the mystic tradition longs to dissolve into or become united with the One in essence. As Huxley asserts "Direct knowledge of the Ground cannot be had except by union, and union can be achieved only by the annihilation of the self-regarding ego, which is the barrier separating the 'thou' from the 'That'" (1970, p. 35).

Mystical experience is a supra-temporal experience during which one manages to transcend the limitation of selfhood, identify with the transcendental Self, and be united with the One. Yet in order to identify the isolated selfhood with the transcendental Self, a complete evacuation of the former is necessary. Heiler labels mysticism as "that form of intercourse with God in which the world and self are absolutely denied, in which human personality is dissolved, disappears and is absorbed in the infinite unity of the Godhead" (1932, p. 136). Through emptying the mind of its contents and detachment from time, space and all worldly attractions, the empirical ego vanishes and the soul is annihilated into the beloved God which is the state of union. This loss of individuality is not annihilation but gaining the only true life as in mysticism "to die to self" is "to be born into eternity" (Johnson, 1993, p. 93). This state is often defined "as a drop of water falling into a river and merging with the sea" (Bell, 2017, p. 539). When the drop merges with the sea, its individuality is annihilated, however, in becoming nothing, it becomes everything.

This state of self-annihilation is referred to as fana in Sufism. The Sufi strives to emerge from a state of egoism to achieve individual salvation through attaining true unity or Tawhid. In fact, as Schimmel asserts "the quintessence of the long history of Sufism is to express anew, in different formulations, the overwhelming truth that 'there is no deity but Allah' and to realize that He alone can be the object of worship" (1975, p. 23). As Burckhardt asserts, Sufism implies a disposition to open oneself to the essential Reality (al-haqiqah), which transcends discursive thought and to gain a possibility of placing oneself intellectually beyond all individual subjectivity $(2008$, p. 10). To achieve this state, Sufism proposes a loss of self through love for the Other in order for the ego to become other to itself and merge with the Other. Junayd, the famous Sufi of the ninth century, claimed that the only means of drawing near to the divine beloved is by constant purification and, in exchange, qualification with God's attributes which can only be brought forth by love: "Love is the annihilation of the lover in His attributes and the confirmation of the Beloved in His essence" (qtd. in Schimmel, 1975, p. 134).

By fana the Sufi means the annihilation of the individual qualities, lifting the veil that separates the primordial beloved from the lover created in time. The tradition "die before ye die" gave the Sufis the possibility of pondering the implications of "the slaying of the lower qualities and the ensuing spiritual resurrection in this life" (Schimmel, 1975, p. 135). With regard to the concept of fana or self-annihilation, Burckhardt argues that instead of identifying himself with his empirical "I" the Sufi fashions that "I" by virtue of an element which is "symbolically and implicitly non-individual" (2008, p. 11). It is the disturbing "I" that stands between lover and the beloved thus for the Sufi the highest aim is the obliteration of the illusory selfhood and absorption into the Eternal Reality. The supreme mystical experience is thus achieved only in union with God. As Chittick argues, when the Sufi travelers "reach the perfection of their own capacity, created in God's image, they experience nothing but the negation of egocentric, separative reality and the affirmation of God-centered, unitive reality" (2000, p. 44). Thus, fana, for the Sufi, is in fact not annihilation at all, but a liberation from the constrictions of the selfhood.

In Sufi tradition, the individual has to pass through several stages in order to attain perfection of self and unification with the Divine. In his quest for complete absorption in God and in the path of love, the Sufi experiences a series of stages known as stations (maqaamaat) and states or internal mode (ahvaal). It is through these stages that love (eshq) could be achieved in the Sufi path since love and gnosis, mahabba and ma'rifa, are the last stations on the mystical path (Schimmel, 1975, p. 130). In Sufism, "spiritual love embraces every individual faculty and imprints each of them with the seal of Unity" since the loftiest station of the soul is "integral love", that is known as the complete absorption of the human will by the Divine attraction. It is the state of being "lost in love" of which Abraham, according to Ibn al-'Arabi, is the human prototype. (Burckhardt, 2008, p. 23-24). Love (al mahabbah), in Sufism, is the beginning of "the valleys of self-annihilation (fana)", which designates extinction of individual limitation in the state of Union with God. Sufism aims to gain access to direct knowledge of the eternal, and the Sufi contemplatives aspire to the spiritual state of baqa, which signifies pure "subsistence" beyond all form (Ibid. p. 3). By passing away (fana) of human attributes through Union with God, the Sufi achieves the eternal subsistence (baqa) of spiritual life in Him. Chittick believes that the concept of fana and baga in Sufism have their roots in the principal of tawhid, the assertion of God's unity, which is expressed most succinctly in the first Shahadah, "There is no God but God" (la ilaha illa Allah): 
... annihilation results from the negation asserted in the first half of the first Shahadah, and subsistence from the affirmation mentioned in the second half. "No god" demands that all the positive qualities and characteristics that are ascribed to creatures be negated from them, because in truth these do not belong to them. "But God" means that God alone can be affirmed as real, so every positive attribute and quality belongs only to Him (Chittick, 2000, p. 44).

Referring to the Sürat al-Fätihah ("The opening one"), Burckhardt reveals the whole idea of fana, baga and the principal unity have been summed up in this verse from Qur'an: "Man's aspiration towards God includes the two aspects expressed in the verse: 'It is Thee whom we adore (or serve) and it is with Thee we seek refuge (or help)'" (2008, p. 40). According to Burckhardt, this verse from Quran reveals that "adoration is the effacing of individual will before the Divine Will which is revealed externally by the sacred Law and inwardly by the movements of Grace", thus the words: "It is Thee whom we adore" correspond to 'extinction' (al-fanä') and the words: 'with Thee we seek refuge' to 'subsistence' (al-baqä') in Pure Being" (Ibid. p. 40). For the Sufis, it is through "fana fillah" (annihilation of the selfhood into God) that "baqa billah" the eternal "subsistence" of spiritual life in Him can be achieved. Chittick explains the expressions "fana" and "baqa", or "annihilation" and "subsistence" as follows:

Through the journey of self-purification and devotion to God, the travelers reach a stage where they become fully open to the divine light, and the brilliance of this light annihilates all the human limitations that had held them back from seeing their true selves and their Lord. The annihilation of obstacles and impediments allows them to see that they themselves had been nothing and still are nothing, because God alone has true reality. Instead of themselves, who had never had any reality to speak of, they now see what subsists after the annihilation of idols and false selfhood. What remains is precisely God in His glory, and this glory demands the shining of His light. According to Rumi's interpretation of Hallaj's scandalous utterance, this is the stage at which he said, "I am the Real" (2000, p. 4344).

According to the Sufis, the self longs for a state of unity in order to overcome its alienation. In Neoplatonist and Sufi traditions, this longing for unity is considered to be rooted in the loss of a primal unity. In Neoplatonist philosophy, "all entities originate in and emanate out of an undifferentiated unity" (Kirschner, 1996, p. 124). Likewise, in Sufism, being "was of an undifferentiated unity interrupted by material creation which resulted in the separation of humanity (as lover) from God (as Beloved)" (Dabashi, 2002, p. 381). The alienation of man from God is not merely the separation between the subject and "the object of his perception", but also "an inner division in man's selfhood" that causes a yearning in man to return to his original state of unity (Kirschner, 1996, p. 161), and it is due to this state of alienation that the soul longs to return to its origin. That is why Rumi opens his most famous work, Mathnavi, with a haunting poem called The Song of the Reed (Nay Namih) which laments the fall and separation of the lover, personified as the reed, from the Fatherland, the reed-bed, and yearns to go back to its origin, the presence of God, the beloved. As Rumi asserts: "Everyone who is left far from his source/ wishes back the time when he was united with it" (Book I. Line. 4)

This return to the origin, as mentioned above, demands a state of unification, a negation of the self, and an extinction in unity (al-fana' $f i$ 'l-tawhid). This yearning for the origin and the lost unity correlates with the Romantic pursuit of a state of reconciliation between the mind of the poet and nature which can be achieved by the poet's progression from a state of selfconsciousness to imagination. In fact, as will be discussed in the next section, the journey for self-liberation and attainment of a state of unification is a recurrent theme in both Sufi and Romantic poetry.

\section{Romantic Longing for Unity and Dissolution of Selfhood}

Mystical death and dissolution of the self is theme that Romantics and Sufi mystics share in common. Similar to mystical tradition, the self in Romanticism longs to dissolve into or become one with the One. It is a type of oneness where the self of the subject is obliterated and annihilated. In fact, the notion of self-loss or dissolution of selfhood has been approached by all the Romantic poets from different perspectives. Coleridge admits that since his childhood he has been accustomed to "unrealize...and then by a sort of transfusion and transmission of my consciousness to identify myself with the Object" (CL IV. 1956, p. 974-75). Similarly, Wordsworth claims: "I was often unable to think of external things as having external existence, and I communed with all that I saw as something not apart from, but inherent in, my own immaterial nature" (qtd. in Symons, p. 149). For Wordsworth, external things have no existence apart from the one eternal and infinite being and it was for "the principle of infinity in them that he loved them" (Ibid. p. 149). Shelley, in his essay On Life (1819) refers to "that state called reverie" where those who have strong imagination may "feel as if their nature were dissolved into the surrounding universe, or if the universe were absorbed into their being. They are conscious of no distinction" (1993, p. 174). Shelley believes the "existence of distinct individual minds similar to that which is employed in now questioning its own nature, is likewise found to be a delusion", consequently, he writes, "The words I, you, they are not signs of any actual difference subsisting between the assemblage of thoughts thus indicated, but are merely marks employed to denote the different modifications of the one mind" (Ibid. p. 174). 
Similarly, Keats, in a letter to Richard Woodhouse in 1818, negates ego-centrism when he says that the "type of poet of which I am a member...has no self...but is continually filling another Body...The sun, the moon, the sea" (2000, p. 895). Furthermore, Keats's famous concept of "Negative Capability" that claims "when a man is capable of being in uncertainties, Mysteries, doubts, without any irritable reaching after fact and reason" (Ibid. p. 889) underlines the negation of the egocentrism and a desire for self-annihilation. For Keats, the true poet is someone who can be empathic toward others and has the ability to lose his selfidentity. In a letter to Richard Woodhouse in 1818, Keats wrote: "As to the poetical Character itself ...it is not itself - it has no self - it is everything and nothing - It has no character - .... A poet is the most unpoetical of anything in existence; because he has no Identity - he is continually in for - and filling some other Body" (2000, p. 895). In Endymion, Keats claims human happiness and eternal salvation lies not only in "that which becks/ Our ready minds to fellowship divine" (Book I, II. 777-78), but in annihilation of one's selfhood and merging with the "orbed drop / Of light" whose influence "genders a novel sense" and that is "love":

At which we start and fret; till in the end,

Melting into its radiance, we blend,

Mingle, and so become a part of it (Ibid. Book I, 809-811).

Hartman argues that in Romanticism two types of self are distinguishable: "the self-conscious self and that self within the self" (1993, p. 48). The self within the self resonates what Shelley in Epipsychidion refers to as "a soul within the soul", which seems like "echoes of an antenatal dream", signifying a spiritual union (1977, Lines. 455-56). In an attempt to reach "the self within the self", the Romantics seeks a form of self-oblivion or self-annihilation in order to overcome the self-consciousness that alienates him from his real self. This alienation urges a sense of constant longing to return to original state of unity. It is what Hartman refers to as the Romantic dream of a return to the imaginative state of non-separateness, "a return to Unity of Being", through surpassing self-consciousness which is "a kind of death-in-life" or "the product of a division in the self" (1993, p. 47).

Shelley approaches the notion of the obliteration of selfhood in his A Defence of Poetry where he regards sympathetic identification or selflessness as a sort of compassion: "The great secret of morals is Love; or a going out of our own nature, and an identification of ourselves with the beautiful which exists in thought, action, or person, not our own" (2000, 796). Having the power to imagine oneself "in the place of another" is thus equal to love for Shelley. A similar idea of annihilation and dissolution of selfhood is vividly expressed in Blake's poem Milton (1810), which asserts that ego-centrism is itself Death and reveals Blake's aspiration to be delivered from the bondage of division:

I will go down to self-annihilation and eternal death

Lest the Last Judgment come and find me unnanihilate

And I be seized and giv'n into the hands of my own Selfhood ...

I in my Selfhood am that Satan: I am that Evil One! $(1907, \mathrm{I}, 10)$

Both in the doctrine and imagery the abovementioned poem by Blake echoes the Sufi concept of fana or the annihilation of the selfhood in the divine consciousness. Annihilation or fana is, in fact, not the same as self-destruction or death at all, but a liberation from the constrictions of the selfhood, as it is well-expressed in Rumi's ghazal in Divan Shams:

Die now, die now, in this Love die; when you have died in this Love, you will all receive new life.

Die now, die now, and do not fear this death, for you will come forth from this earth and seize the heavens.

Die now, die now, and break away from this carnal soul, for

this carnal soul is as a chain and you are as prisoners.

Take an axe to dig through the prison; when you have broken

the prison you will all be kings and princes. (1968, trans. by Arberry, p. 105)

As Rumi reveals in the above poem, we are all prisoners and it is through dying in the love of God and breaking away from the "carnal soul", that one can receive new life. This means that through dissolution of selfhood, one can achieve what is known in Sufi terminology as "subsistence-in-God" (baqa), an idea that Blake also refers to in his Milton:

I come to Self Annihilation.

Such are the Laws of Eternity, that each shall mutually

Annihilate himself for others' good, as I for thee.

Thy purpose \& the purpose of thy Priests \& of thy Churches

Is to impress on men the fear of death, to teach

Trembling \& fear, terror, constriction, abject selfishness. 
Mine is to teach Men to despise death \& to go on

In fearless majesty annihilating Self, laughing to scorn

Thy Laws \& terrors, shaking down thy Synagogues as webs.

I come to discover before Heav'n \& Hell the Self righteousness

In all its hypocritic turpitude... to put off

In Self annihilation all that is not of God alone,

To put off Self \& all I have, ever \& ever. Amen. (1907, p. 41)

Similarly, Rumi asserts that if one denies and annihilate his carnal self, he can found the higher form of existence that is subsistence in God (baqa), thus he upbraids those who "shrink annihilation" and encourage his readers to seek annihilation since the latter is superior to the our current state:

You have obtained these existences after annihilations;

Wherefore, then, do you shrink from annihilation?

What harm have these annihilations done you

That you cling so to present existence, O simpleton?

Since the latter of your states were better than the former,

Seek annihilation and adore change of state.

(Mathnavi, Book V. Lines. 339-340, trans. Nicholson, 1985).

Rumi's advice here resembles what Shelley says in his ode, Adonais (1821), where he urges his friend Keats to seek annihilation so as to transcend divisions and achieve unity:

Die!

If thou wouldst be with that which thou dost seek!

Follow where all is fled!- Rome's azure sky,

Flowers, ruins, statues, music, words, are weak

The glory they transfuse with fitting truth to speak.

...

'Tis Adonais calls! Oh, hasten thither,

No more let Life divide what Death can join together. (2000, Lines, 464-68, 476-77)

And finally, perhaps the most beautiful expression of the Sufi concepts of "fana fillah" can be seen in Wordsworth's Tintern Abbey (1789), when Wordsworth relates his experience of a trancelike state of that "serene and blessed mood"

In which the affections gently lead us on,

Until, the breath of this corporeal frame

And even the motion of our human blood

Almost suspended, we are laid asleep

In body, and become a living soul:

With an eye made quiet by the power

Of harmony, and the deep power of joy,

We see into the life of things. (Lines 42-49)

In a moment of quiet contemplation, Wordsworth experiences a state of illumination in which the burden of "this unintelligible world", that is, of the questioning intellect which creates divisions, "Is Lightend". In an imaginative state, Wordsworth transcends his sensual eyes and manages to see with the eye of the mind which is capable of perceiving "harmony" and "joy". The lines "the motion of our human blood/ Almost suspended, we are laid asleep/ in body" resonates the Sufi concept of self-annihilation or "fana fillah", and "become a living soul" resembles subsistence in God or "baqa billah", while to "see into the life of things" echoes the highest stage of fana that is the perception of unity of being and a state of harmony and unification with all that exist.

\section{Conclusion}

The present paper endeavored to reveal that despite the time span of about six centuries, geographical distance, ideological and cultural distinctions and theological divergence that separate the Romantic poets from classical Sufi mystics and poets, viewed from an anagogic perspective, the Romantics' yearning for the coalescence of the subject/object dualism through imagination and intuitive perception resonates the Sufi's mystical goal of identification of the temporal selfhood with the transcendental Self or the Sufi concept of Fana. This study illustrates that both the Sufis and Romantic texts recount the story of the movement of 
consciousness and the longing of the self to transcend self-consciousness to merge with something greater than the self. It has been depicted that the Romantic poet, like the Sufi mystic, seeks ultimate union with the divine, a desire which necessitates the subject's own dissolution and annihilation. However, there has been no intention to exaggerate these similarities or to prove that the one is derived from the other. Many things can be similar without being derived from one another. This can be particularly true in mystical traditions as mystics in all ages and countries have shown a tendency to describe common experiences in more or less similar imageries. Thus there is more room for making comparisons regarding common themes, motifs, archetypes, rhetorical and poetic forms between different mystical traditions.

To sum up, at a time when cultural, ideological, national and religious differences lead to conflicts among nations and have become an instrument of political domination and a reason for wars in many parts of the world, perhaps investigation for commonalities in art and literature of different nations can help overcome such prejudices and reveal that there is fundamental unity in human mind since as Hafez, the renowned Persian poet of the fourteenth century, proclaims all the various faiths and sects of mankind are multiple expressions of a single Truth so he says: "The wrangle of the seventy-two sects, establish excuse for all/ When truth, they saw not, the door of feeble they beat" (Divan Hafez, n. 179). Furthermore, cross-cultural studies in comparative literature demonstrate that when it comes to art and literature, geographical distance or cultural differences evaporate since literature at the anagogic level transcends cultural or theological confinements and is viewed as "existing in its own universe, no longer a commentary on life or reality, but containing life and reality in a system of verbal relationships" (Frye, 1957, p. 122). Therefore it would not be out of context to end this paper by referring to a poem by Rumi in his Divan Shams where he invites all people to transcend the confine of selfhood and see the inherent unity of all beings within the apparent multiplicity:

Come forth, away from this waywardness

If you are me and me you, whence this you-and-me [duality]?

A light from God are we and the glass [of light] does not cover itself

Why would then escape light from light

We are one substance, one reason and one head

Double-visioned though we have become all because of this curved firmament

Away from these five [senses] and six [spatial directions] and toward Oneness

How long will you keep mouthing the sound of Oneness

Break away from I and dissolve into the all

With yourself, you are but a grain, with all a mine

The soul sends messages to any observing one

If through Oneness you depart from words (my translation, Ghazal no. 3020)

\section{References}

[1] Abrams, M. H. (1973). Natural Supernaturalism: Tradition and Revolution in Romantic Literature. W. W. Norton \& Company.

[2] Arberry, A. J. (1968). The Mystical Poems of Rumi. Chicago: University of Chicago Press.

[3] Bell, David N. (2017). A Saint in the Sun: Praising Saint Bernard in the France of Louis XIV. Liturgical Press.

[4] Blake, William. (1907). The Prophetic Books of William Blake. Eds. E. D. Maclagan et al. Chiswick Press.

[5] Blake, William. (1982). The Complete Poetry and Prose of William Blake. Ed. David. V. Erdman. University of California Press.

[6] Burckhardt, Titus. (2008). Introduction to Sufi Doctrine. World Wisdom Inc.

[7] Chittick, William C. (2000). Sufism: A Beginner's Guide. Oxford University Press .

[8] Chittick, William C. (2005). Ibn 'Arabi: Heir to the Prophets. Oneworld.

[9] Chittick, William C. (2016). "Ibn al- 'Arabī: The Doorway to an Intellectual Tradition". Journal of the Muhyiddin Ibn 'Arabi Society. Vol. 59, 115.

[10] Coleridge, Samuel Taylor (1975). Biographia Literaria. J. M. Dent.

[11] Coleridge, Samuel Taylor. (1972). Statesman's Manual in Lay Sermons, ed. R. J. White, vol. 6 of The Collected Works of Samuel Taylor Coleridge. Bollingen Series, Princeton, N.J.

[12] Coleridge, S. T. (1956). Collected Letters of Samuel Taylor Coleridge. Ed. E. L. Griggs. The Clarendon Press.

[13] Dabashi, Hamid. (2002). "Ayn al-Qudat Hamadani and the Intellectual Climate of his Times". In Seyyed Hossein Nasr and Oliver Leaman (Ed.), History of Islamic Philosophy. 2 vols. (pp. 374-419). Routledge.

[14] Engell, J. (1981). The Creative Imagination: From Enlightenment to Romanticism. Cambridge University Press.

[15] Frye, Northrop. (1957). Anatomy of Criticism: Four Essays. Princeton University Press.

[16] Hafez. (2001). Ghazal of Hafez Shirazi: In Persian with English Translation, trans. by Henry Wilberforce Clarke, compiled and corrected by Behrouz Homayoun Far.

[17] Hartman, Geoffery. (1993). "Romanticism and Anti-Self-Consciousness." In Cynthia Chase (Ed.), Romanticism (pp. 43-54). Routledge.

[18] Heiler, Friedrich. (1932). Prayer: A Study in the History and Psychology of Religion. Oxford University Press.

[19] Huxley, A. (1970). The Perennial Philosophy. Chatto and Windus. 
[20] Johnson, J. (1993). The Path of the Masters: The Science of Surat Shabd Yoga, the Yoga of the Audible Life Stream. Rada Soami Satsang Beas.

[21] Keats, J. (2000). Endymion: A Poetic Romance. In Stephen Greenblatt et al (Eds.), Norton Anthology of English Literature, Vol 2. Seventh Ed. (pp. 829-833). W. W. Norton.

[22] Keats, J. (2000). The Fall of Hyperion. In Stephen Greenblatt et al (Eds.), Norton Anthology of English Literature, Vol 2. Seventh Ed. (pp.829833). W. W. Norton.

[23] Keats, J. (2000). 'Letters'. In Stephen Greenblatt et al (Eds.), Norton Anthology of English Literature, Vol 2. Seventh Ed. (pp. 887-903). W. W. Norton.

[24] Kirschner, S. (1996). The Religious and Romantic Origins of Psychoanalysis: Individuation and Integration in Post-Freudian Theory. Cambridge University Press.

[25] Lewisohn, Leonard. (2009). "Correspondence Between English Romantic and Persian Sufi Poets: An Essay in Anagogic Criticism". Temenos Academy Review. Vol 12, 185-226.

[26] Moores, D. J. (2006). Mystical Discourse in Wordsworth and Whitman: A Transatlantic Bridge. Peeters.

[27] Nicholson, Reynold. (1985). The Mathnavi of Jalaluddin Rumi. 3 Vols. Gibb Memorial Trust.

[28] Perkins, Mary Anne. (2002). "Religious Thinker." In Lucy Newlyn (Ed.), The Cambridge Companion to Coleridge. (pp 187-199). Cambridge University Press.

[29] Ryan, Robert M. (1997). The Romantic Reformation: Religious Politics in English Literature 1789-1824. Cambridge University Press.

[30] Schimmel, Annemarie, (1975). Mystical Dimensions of Islam. University of North Carolina Press.

[31] Shelley, Percy Bysshe (1993). The Prose Works of Percy Bysshe Shelley. Ed. E. B. Murray. Vol. 1. Clarendom.

[32] Shelley, Percy Bysshe (1977). Epipsychidion. In Donald H. Reiman and Sharon B. Powers (Eds.), Shelley's Poetry and Prose: Authoritative Texts Criticism. W. W. Norton \& Company.

[33] Shelley, Percy Bysshe (2000). A Defence of Poetry. In Stephen Greenblatt et al (Eds.), Norton Anthology of English Literature. Vol. 2. Seventh Ed. (pp. 790-802). W. W. Norton.

[34] Shelley, Percy Bysshe (2000). Adonais. In Stephen Greenblatt et al (Eds.), Norton Anthology of English Literature. Vol. 2. Seventh Ed. (pp. 772782). W. W. Norton.

[35] Symons, Arthur. (1902). "Wordsworth". InmHarold Bloom (Ed.), Bloom's Classic Critical Views: William Wordsworth. (2009) (pp. 138-150). Infobase Publishing.

[36] Wordsworth, Jonathan. (1999) "The Romantic Imagination." In Duncan Wu (Ed.), A Companion to Romanticism (pp.525-533). Blackwell Publishing Ltd.

[37] Wordsworth, William. (2010). The Prelude (1805). In Stephen Gill (Ed.), 21st- Century Oxford Authors: William Wordsworth. Oxford University Press.

[38] Wordsworth, William. (2010). Tintern Abbey. In Stephen Gill (Ed.), 21st- Century Oxford Authors: William Wordsworth. Oxford University Press.

[39] Underhill, Evelyn. (1911). Mysticism: A Study of the Nature and Development of Man's Spiritual Consciousness. E. P. Dutton \& Co.

[40] Underhill, Evelyn. (1920). The Essential of Mysticism and Other Essays. E. P. Dutton \& Co. 